\title{
Heat-Intolerance Syndrome subsequent Foot-and-Mouth Disease in Cattle; ThiQar -Iraq
}

\author{
Adil M. Abbas ${ }^{1}$,Mohammed A. Y. Al-Amery ${ }^{2}, \quad$ Abbas Y. J. Al-Mousawy ${ }^{2}$ \\ and Jalel A. Gati ${ }^{1}$ \\ 1 -Vet hospital of ThiQar- Ministry of agriculture, 2-College of veterinary medicine- \\ University of Basra
}

\section{Summary}

The investigation on Heat-Intolerance Syndrome following foot and mouth disease (FMD) infection in cattle in ThiQar-Iraq, used 3ABC FMD ELISA kit, and Radio- immunoassay (RIA) to detect the cortisol level. From 105 there were 65(62\%) infected cattle with FMD, which was high at 5- less 8 years old, while the cortrisol level showed three levels; normal (13-21 nmoh), high and low levels were; 6(5.6\%), 44(42\%) and 55(52\%) subsequently. More over the combined result of ELISA and RIA had divided cattle into six groups. First group of $40(38 \%)$ cattle infected with FMD and had low level of cortisol, this group containing 21(20\%) with clinical signs of heat intolerance. Second group contain $22(21 \%)$ FMD infected cattle with high level of cortisol. Third group of 3(2.8\%) FMD Infected cattle but normal cortisol level. Fourth group included 3(2.8\%) not infected by FMD with normal cortisol level. Fifth group contain 22(21\%) not infected with FMD but had high level of cortisol may related to stress. Sixth group consisted 15 (14\%) cattle not infected with FMD and had low level of cortisol due to un known cause.

Clinical signs of heat intolerance that showed in 21 head of cattle in the first group were: panting, overgrowth of hair coat, emaciation and seeking for shad. The diseased cow known locally as "Mahrorah" meaning heat-intolerance.

Keywords: Heat-Intolerance , FMD, Cattle, ABC- ELISA, RIA, cortisol, ThiQar, Iraq
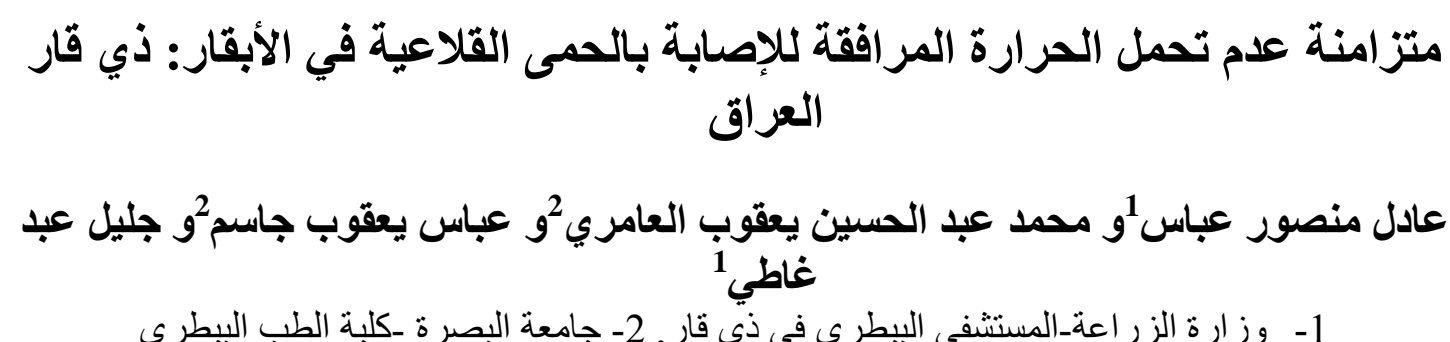

الخلاصة

عدت هذه الدراسة للتحري عن منزامنة عدم تحمل الحرارة بعد الإصابة بمرض الحمى القلاعية في الأبقار في

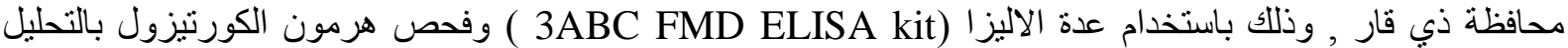
الاستشعاعي الممنع لمصل الدم من خلافل فحص فل (105) رأسا من الأبقار وجد 65(62\%) مصابا بالحمى القلاعية وكانت

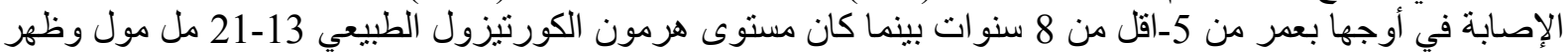

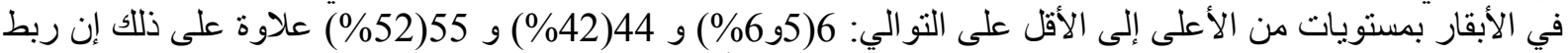

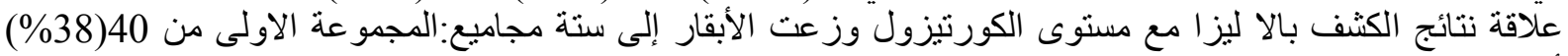

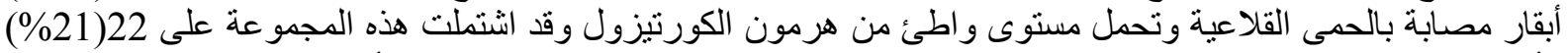

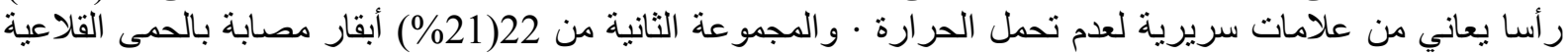

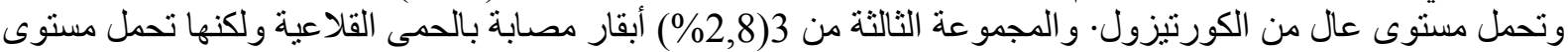
طبيعي للكورتيزول , و المجموعة الرابعة شملت 3(2,8\%) أبقار غير مصابة بالحمى القلاعية وكذلك ذات كورتيزول بمستوى طبيعي , والمجموعة الخامسة تألفت من 22(21\%) أبقار غير مصنة مصابة بالحمى القلاعية ولكنها تحمل مستويات عالية من الكورتيزول ربما بسببالإجهاد, و المجمو عة السادسة كانت من 15(14\%) أبقار غير مصابة بالحمى القابلاعية مع

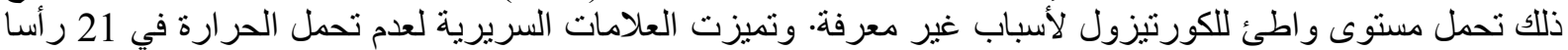

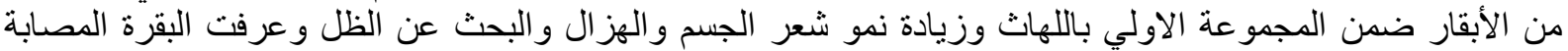

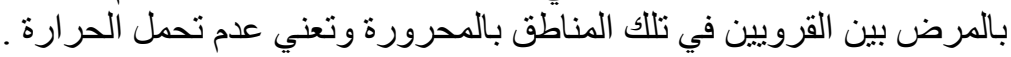




\section{Introduction}

Foot-and-mouth disease (FMD) is highly contagious viral disease of cloven-hoofed domestic and wild animals. It is widely distributed and occurs most commonly in Asia and Africa (1). FMD is caused by a virus of the Aphthovirus genus within the family Picornaviridae (2). There are seven FMDV serotypes O,A,C, Asia-1,South African Territories types (1,2 and 3) and immunity to one does not cross-protect against the others(3).

The FMD virus serotypes that detected in Iraq were; serotype A since 1952, O in 1957 , SAT 1 in 1962 and Asia 1 in 1975, but most recent outbreaks were due to O and A strains during years $2000-2009$ (4 ; 5 , 6). The FMD WRL (Pirbright, UK) report suggests the last outbreak was caused by emerging strain A-Iran-05 (7).

As a sequel of foot-and-mouth disease, a proportion of infected cattle develop dyspnoea, long and rough coats, poor body condition and chronic, irreversible impairment of production potential. These cattle are colloquially known as "panters "in India (8 ). In the late 1999s, a syndrome of heat intolerance and overgrowth of hair in cattle was reported by workers in Morogoro region, Tanzania (9). Cattle with Heat Intolerance manifested by loss body condition, and reduced milk production (10).

So This study aimed to determine the Heat Intolerance Syndrome as a sequel of foot-and mouth disease in cattle in ThiQar province.

\section{Equipments;}

\section{Materials and methods}

- Microplate washer / Gesellschaft für Biochemica and Diagnostica / Germany

- ELISA Reader / Dia Med Euro Gen / Belgium..

- RIA gamma counter/Block Scientic/ Englewood,NJ 07631

Cattle; 105 cattle were chosen in a period distended from 7 to 26 October 2009, from ten villages at four- directions in ThiQar ( north, east, south and west).

Blood Samples; were collected from a jugular vein of cattle into $10 \mathrm{ml}$ sterile vacuum tubes without anticoagulant, serum separated by centrifuging (3000rpm for 5 minutes). (TABLETOP / Germany), then stored at $-20 \mathrm{C}^{\circ}$ until assayed.

Confirm the FMD infection by using 3ABC-Ab FMD ELISA kit ( Svanova /Sweden), to differentiate the naturally infected animals from those vaccinated with the FMD virus , and the procedure was according to company instruction, and corrected OD values(ODcorr) as the following equation;

$\mathrm{OD}_{\mathrm{Nsp} 3 \mathrm{ABC} \_} \mathrm{OD}_{\text {control }}=\mathrm{OD}_{\text {corr }}$

While the percent positivity Value (PP) as in;

$$
\mathrm{PP}=\frac{\text { Test Sample or Neg(ODcorr) }}{\text { Positive Control(ODcorr) }} \times 100
$$

Then the Interpretation of test sample result as below;

$\begin{array}{lll}\text { Serum } & \text { PP } & \text { Interpretation } \\ & <48 & \text { Negative } \\ & \geq 48 & \text { Positive }\end{array}$

Estimation of cortisol level by using Cortisol RIA kit.( Beckman Coulter Company), the assay procedure was done according to company instructions.

\section{Results}

Among 105cattle of the studied population from ThiQar province there were $65(62 \%)$ positive for ELISA, the infection was high in age group 5-<8 years old 20(19.1\%) (table1). 
Proceeding of the Eleventh Veterinary Scientific Conference, 2012; 286 -292

Table(1): The result of ELISA according to the age group of cattle

\begin{tabular}{|c|c|c|c|c|c|}
\hline \multicolumn{2}{|l|}{ Cattle } & \multicolumn{2}{|c|}{ ELISA Positive } & \multicolumn{2}{|c|}{ ELISA Negative } \\
\hline Age(years & number & number & percentage & number & percentage \\
\hline $1-<2$ & 21 & 14 & $(13.3 \%)$ & 7 & $(6.6 \%)$ \\
\hline $2-<5$ & 25 & 16 & $(15.2 \%)$ & 9 & $(8.6 \%)$ \\
\hline $5-<8$ & 32 & 20 & $(19.1 \%)$ & 12 & $(11.4 \%)$ \\
\hline 8and over & 27 & 15 & $(14.3 \%)$ & 12 & $(11.4 \%)$ \\
\hline The total & 105 & 65 & $(62 \%)$ & 40 & $(38 \%)$ \\
\hline \multicolumn{2}{|c|}{ P-value $=0.869 \quad(P>0.05)$} & \multicolumn{2}{|c|}{$\mathrm{X}^{2}=\mathbf{0 . 7 1 5}$} & of free & $=3$ \\
\hline
\end{tabular}

From the total of 105 serum samples of cattle measured by RIA, the cortisol increased in $44(42 \%)$ samples while it was low in 55(52\%), but the normal were found in $6(5.7 \%)$ as shown in the table (2) .

Table(2): RIA Result of cortisol

\begin{tabular}{|c|c|c|c|c|c|c|c|}
\hline \multicolumn{2}{|l|}{ Cattle } & \multicolumn{2}{|c|}{$\begin{array}{l}\text { High level } r \\
\text { Cortisol }(>0.75\end{array}$} & \multicolumn{2}{|c|}{$\begin{array}{l}\text { Low level of } \\
\text { Cortisol }\end{array}$} & \multicolumn{2}{|c|}{$\begin{array}{l}\text { Normal Level Of } \\
\text { Cortisol }(\mathbf{0 . 4 7 - 0 . 7 5 )} \mu \mathrm{g} /\end{array}$} \\
\hline Age(years) & number & Humber & percentage & number & percentage & Number & Percentage \\
\hline $1-<2$ & 21 & 11 & $(10.5 \%)$ & 7 & $(6.5 \%)$ & 3 & $2.9 \%$ \\
\hline $2-<5$ & 25 & 15 & $(14.3 \%)$ & 9 & $(8.5 \%)$ & 1 & $0.9 \%$ \\
\hline $5-<8$ & 32 & 10 & $(9.5 \%)$ & 21 & $(20 \%)$ & 1 & $0.9 \%$ \\
\hline 8and over & 27 & 8 & $(7.7 \%)$ & 18 & $(17 \%)$ & 1 & $0.9 \%$ \\
\hline The total & 105 & 44 & $(42 \%)$ & 55 & $(52 \%)$ & 6 & $5.6 \%$ \\
\hline \multicolumn{4}{|c|}{ P-value $=0.028 \quad(P<0.05)$} & \multicolumn{2}{|c|}{$X^{2}=9.027$} & \multicolumn{2}{|c|}{ Df $=\mathbf{3}$} \\
\hline
\end{tabular}

The combination between ELISA \& RIA Results to six groups illustrated in tables(3, 4,5,6,7 and 8):

Table (3): first group ELISA positive and cortisol at low level, and 21 cattle with a clinical findings of heat intolerance.

\begin{tabular}{|c|c|c|c|c|c|c|c|}
\hline \multicolumn{2}{|l|}{ Cattle } & \multicolumn{2}{|c|}{$\begin{array}{l}\text { ELISA Positive and } \\
\text { Cortisol at low level }(< \\
0.47 \mu \mathrm{g} / \mathrm{dL})\end{array}$} & \multicolumn{2}{|c|}{$\begin{array}{l}\text { Cows with Clinical } \\
\text { findings }\end{array}$} & \multicolumn{2}{|c|}{$\begin{array}{l}\text { Cows without } \\
\text { Clinical findings }\end{array}$} \\
\hline $\begin{array}{l}\begin{array}{l}\text { Age } \\
\text { (years) }\end{array}\end{array}$ & Number & $\begin{array}{l}\text { Numb } \\
\text { er }\end{array}$ & Percentage & No. & Percentage & No. & Percentage \\
\hline $1-<2$ & 21 & 6 & $(5.7 \%)$ & 1 & $(0.9 \%)$ & 5 & $4.7 \%$ \\
\hline $2-<5$ & 25 & 7 & $(6.6 \%)$ & 4 & $(3.8 \%)$ & 3 & $2.9 \%$ \\
\hline $5-<8$ & 32 & 16 & $(15.2 \%)$ & 11 & $(10.5 \%)$ & 5 & $4.7 \%$ \\
\hline 8and over & 27 & 11 & $(10.5 \%)$ & 5 & $(4.8 \%)$ & 6 & $5.7 \%$ \\
\hline The total & 105 & 40 & $(38 \%)$ & 21 & $(20 \%)$ & 19 & $18 \%$ \\
\hline \multicolumn{4}{|c|}{$\begin{array}{lll}\text { Pvalue }=0.609>0.05 & X^{2}=1.825 & D f= \\
3 & \end{array}$} & \multicolumn{2}{|c|}{$\begin{array}{l}\text { Pvalue }=0.646>0.05 \\
=3\end{array}$} & & 659 \\
\hline
\end{tabular}

Out of 40 cattle of the first group, there were 21 cattle had signs of heat intolerance that given in table (3), included stopped grazing and eating, loss body weight. It is also founded that for moost time preferred to stand under the shade and dose not tolerated sun light. closer . Close examination showed panting with respiratory rate(68-76) per minute and body temperature(39.5-39.7) $\mathrm{C}^{\circ}$, also there was overgrowth of hair coat particularly at the areas like withers, chest, along the back and on the flanks and easily determined the ribs which revealed emaciation and loss of body weight, such animals the farmers called them "Mahrorah". 
Table (4): The second group with ELISA posetive and cortisol at high level

\begin{tabular}{|c|c|c|c|}
\hline \multicolumn{2}{|l|}{ Cattle } & \multicolumn{2}{|c|}{$\begin{array}{l}\text { ELISA Positive and Cortisol at high level }(>0.75 \\
\mu \mathrm{g} / \mathrm{dL})\end{array}$} \\
\hline Age (years) & Number & Number & Percentage \\
\hline $1-<2$ & 21 & 6 & $(5.7 \%)$ \\
\hline $2-<5$ & 25 & 8 & $(7.6 \%)$ \\
\hline $5-<8$ & 32 & 4 & $(3.8 \%)$ \\
\hline 8 and over & 27 & 4 & $(3.85)$ \\
\hline The total & 105 & 22 & $(21 \%)$ \\
\hline \multicolumn{2}{|c|}{ P-value $=0.399>0.05$} & Df $=3$ & \\
\hline
\end{tabular}

Table(5): The third group ELISA Positive and Cortisol at Normal level

\begin{tabular}{|l|c|c|c|}
\hline \multicolumn{2}{|l|}{ Cattle } & \multicolumn{2}{c|}{$\begin{array}{c}\mu L I S A \\
\mathrm{gg} / \mathrm{dL}\end{array}$} \\
\hline Age (years) & Number & number & percentage \\
\hline $1-<2$ & 21 & 2 & $(1.9 \%)$ \\
\hline $2-<5$ & 25 & 1 & $(0.9 \%)$ \\
\hline $5-<8$ & 32 & zero & $(0 \%)$ \\
\hline 8 and over & 27 & zero & $(0 \%)$ \\
\hline The total & 105 & 3 & $2.8 \%$ \\
\hline P-value $=\mathbf{0 . 1 8 8}>\mathbf{0 . 0 5}$ & $\mathbf{X}^{\mathbf{2}}=\mathbf{4 . 7 7 8}$ & Df $\mathbf{3}$ \\
\hline
\end{tabular}

Table(6 ): The fourth group ELISA Negative and Cortisol Normal

\begin{tabular}{|c|c|l|c|}
\hline \multicolumn{2}{|c|}{$\begin{array}{c}\text { Cattle } \\
\text { Age } \\
\text { (years) }\end{array}$} & er & ELISA Negative and Cortisol Normal $(0.47-0.75) \mu \mathrm{g} / \mathrm{dL}$ \\
\hline $1-<2$ & 21 & 1 & Percentage \\
\hline $2-<5$ & 25 & zero & $(0.9 \%)$ \\
\hline $5-<8$ & 32 & 1 & $(0.0 \%)$ \\
\hline 8 and over & 27 & 1 & $(0.9 \%)$ \\
\hline Total & 105 & 3 & $(0.9 \%)$ \\
\hline P-value $=\mathbf{0 . 7 8 1}>\mathbf{0 . 0 5}$ & $\mathbf{X}^{2}=\mathbf{1 . 0 4 2}$ & $(2.8 \%)$ \\
\hline
\end{tabular}

Table (7): The fifth Group, ELISA Negative and Cortisol at high level

\begin{tabular}{|l|l|c|c|}
\hline \multicolumn{2}{|c|}{ Cattle } & $\begin{array}{c}\text { ELISA Negative and Cortisol at high level ( }> \\
0.75 \mu \mathrm{g} / \mathrm{dL})\end{array}$ \\
\hline Age (years) & Number & Number & percentage \\
\hline $1-<2$ & 21 & 5 & $(4.7 \%)$ \\
\hline $2-<5$ & 25 & 7 & $(6.7 \%)$ \\
\hline $5-<8$ & 32 & 6 & $(5.7 \%)$ \\
\hline 8 and over & 27 & 4 & $(3.8 \%)$ \\
\hline The total & 105 & 22 & $(21 \%)$ \\
\hline P-value=0.797 $>\mathbf{0 . 0 5}$ & $\mathbf{X}^{\mathbf{2}} \mathbf{\mathbf { 1 . 0 1 4 }}$ & Df=3 \\
\hline
\end{tabular}


Proceeding of the Eleventh Veterinary Scientific Conference, 2012; 286 -292

Table (8): The sixth group ELISA Negative and cortisol at low level

\begin{tabular}{|c|c|c|c|}
\hline \multicolumn{2}{|l|}{ Cattle } & \multirow{2}{*}{\multicolumn{2}{|c|}{$\begin{array}{l}\text { ELISA Negative and Cortisol at low level } \\
(<0.47 \mu \mathrm{g} / \mathrm{dL})\end{array}$}} \\
\hline Age(Years) & Number & & \\
\hline $1-<2$ & 21 & 1 & $(0.9 \%)$ \\
\hline $2-<5$ & 25 & 2 & $(1.9 \%)$ \\
\hline $5-<8$ & 32 & 5 & $(4.7 \%)$ \\
\hline 8 and over & 27 & 7 & $(6.6 \%)$ \\
\hline The total & 105 & 15 & $(14 \%)$ \\
\hline$P$-value $=0.26$ & $X^{2}=3.981$ & Df $=3$ & \\
\hline
\end{tabular}

In association between ELISA and cortisol with exception of normal cortisol results that mean first(table-3), second(table-4), fifth(table-7) and sixth(table-8) groups were included as in table(9), whereas significant negative correlation $(\mathrm{P}<0.05)$ between FMD antibody titter and serum cortisol level.

Table(9) FMD ELISA results and cortisol (low and high) level associations

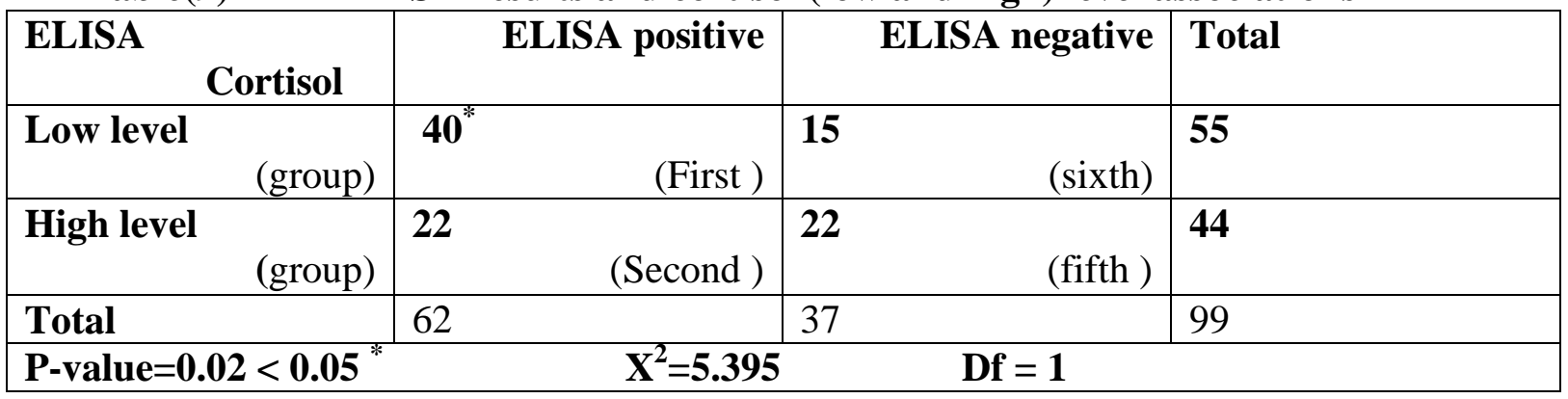

\section{Discussion}

The investigation about heat intolerance syndrome in ThiQar province by using 105 head of Cattle was disclosed a clinical findings in 21(20\%) cattle which included panting, high body temperature, overgrowth hair coat and loss of body weight were also seen by (11) following FMD infection as a sequel called heat intolerance.

The high temperature of $39.5-39.7 \mathrm{C}^{\circ}$ was related to imbalance between heat gain and heat loss, the haemostatic responses such increased respiratory rate and more obvious panting to compensate elevated temperature were overwhelmed (12). The heat regulation function in hypothalamus was damaged by FMD virus (13), more over the loss of body weight for reason that affected cow was stop grazing, eating and walking to food, then became starved and emaciated (14).

The ELISA result from 105 there were 65(62\%) FMD infected cattle, that in respective to serotypes, the ratio was relatively nearer to previous study by (15) whom founded infection ratio $61,42 \%$ in the middle and south of Iraq as endemic regions.

The used RIA for 105 cattle appeared three levels of cortisol ; high level(more than $21 \mathrm{nmoh})$ in the $44(42 \%)$ cattle which may related to stress a procedure of jugular blood collection for serum, that (16) had demonstrated that animals were significantly stressed by routine husbandry procedures . the low level (less than $13 \mathrm{nmoL}$ ) in $55(52 \%)$ cattle were also exposed to same procedure by blood collection method whereas not responded, given an indication to damage on endocrine system, because corticotrophic releasing hormons was released from the hypothalamus into the portal veins of the pituitary gland and adrinocorticotrophic hormone secreted from the frontal lobe into blood stream which stimulated the adrenal cortex by releasing cortisol ( 17).

Normal level of cortisol $(13-21 \mathrm{nmoh})$ was founded in $6(5.6 \%)$ cattle which were not stimulated by stress procedure of blood collection (18), and some cattle had adaptive coping 
by endogenous pain inhibitory system, as well as phenomenon termed stress- induced analgesia (19).

The combination between ELISA and RIA results reviled four groups of cattle, first group with ELISA positive and cortisol at low level, included 40(38\%) head of previously infected cattle by FMD virus, the reduction of cortisol level was also observed in primary or secondary hypoadrenocorticism, which manifested by low cortisol production and blood levels resulted from low adrenal cortisol released in response to adrinocorticotrophic hormones(ACTH) stimulation because of the factors such as low adrenal mass and atrophy or destruction of the adrenal cortices. On other hand, the secondary hypoadrenocorticism may result from low pituitary ACTH production (20), so their is possible of secondary hypoadrenocortism is the cause of low cortisol level as several report have demonstrated FMD virus replication in pituitary gland of affected animals and significant reduction in blood cortisol level in cattle with heat intolerance syndrome which also agreement with (11).

The second group with ELISA positive and cortisol at high level, included 22(21\%) head of previously infected cattle by FMD virus and recovered as a carrier which were stressed by procedure of blood collection, in agreement with $(21,22)$.

The third group ELISA Positive and Cortisol at normal level included 3(2.8\%) head of previously cattle were infected with FMD virus then recovered from the disease to become a carrier, such reason was explained by (23) who was differentiated the carrier state of FMD in cattle by asymptomatic persistent infection, followed the acute face of infection, but the recent group was not stressed by the procedures of blood collection.

The fifth Group, ELISA Negative and Cortisol at high level contain 22(21\%) cattle not infected previously by FMD virus, those cattle may stressed by procedures of blood collection , similar stress was defined by (24) as a physiological response to events perceived as a potentially or actually threatening the integrity of the animal body, whereas serum cortisol was used as stress indicator when demonstrated by elevating blood cortisol level in mammal species.

The sixth group ELISA Negative and cortisol at low level included 15(14\%) cattle were not infected by FMD virus for at least one year ago until time of blood collection due to their immunity which resist FMD infection but they may suffer from another disease state that reflected by decreased level of cortisol in their serum although the cattle were stressed by procedure of blood collection(11, 20$)$.

According to Table(9) the correlation between FMD infected or non and abnormality of cortisol levels appeared that infected cattle by FMD virus like first group were significantly affected by decreased cortisol levels may due to damaged their pituitary gland (20), on other hand result was reversed by high cortisol levels for non infected cattle in the present study

In conclusion the cattle in ThiQar province had incidence of FMD virus infection of $62 \%$ also there was $38 \%$ of cattle in the endemic region were suffer from heat intolerance syndrome with low serum cortisol level as well as most of them had Clinical signs: panting, overgrowth of hair coat, emaciation and seeking for shad, which well known locally as "Mahrorah" cow, meaning heat-intolerance.

\section{References}

1. Rufael T,Catley A, Bogale A, Sahle M, Shiferaw Y. (2008).Participatory epidemiology as compared to conventional foot and mouth disease surveillance tool. Appendix;62:353-360.

2. Donaldson AI. (1987). Foot and mouth disease ,the principal features. Irish Vet J;41:325-327.

3. Brehm KE, Kumar N, Thulke HH, Haas B. (2008). High potency vaccines induce protection against heterologous challenge with foot and mouth disease virus .Vaccine;26:1681-1687.

4. Aidaros HA.( 2002). Regional status and approaches to control and eradication of foot and mouth disease in the Middle East and North of Africa. Rev Sci Off Int Epiz;21:451- 458. 
5. FAO/OIE. (2002). Global FMD situation during 2001/2002. Report of FAO/OIE World Reference Laboratory for FMD, institute for Animal Health, Ash Road, Pirbright, working, surry GU24 ONF, United kingdom. Appendix;2:49-56.

6. FAO/OIE. (2009). Annual OIE / FAO, FMD References Laboratory Network Report. January - December. Pp. 25-39.

7. Global Animal Health. (2009). International Disease Monitoring Preliminary Outbreak Assessment, Foot and mouth disease in cattle in Kuwait.

8. Sanson RL. (1993). The development of a decision support system for an animal disease emergency .A thesis of philosophy at Massey University, chapter one, pp:1-24.

9. Makene VW. (1998). Heat intolerance associated with foot and mouth disease in cattle : occurrence ,behaviour and physiological parameters. Master thesis, Sokoine University of Agriculture.

10. Catley A, Chibunda RT, Ranga E, Makungu S, Magayane FT, Magoma G, Madege MJ, Vosloo W. (2004). Participatory diagnosis of a heat -intolerance syndrome in cattle in Tanzania and association with foot and mouth disease. Preventive Veterinary Medicine; 65:17-30.

11. Ghanem MM, Abdel -Hamid OM. (2010). Clinical, haematological and biochemical alterations in heat intolerance (panting ) syndrome in Egyptian cattle following natural foot and mouth disease (FMD). Springer Science, Business Media B. V.

12. Dunlop R.H and Malbert, C.H. (2004). Veterinary pathophysiology , $1^{\text {st }}$ ed. Blackwell publishing, 544p.

13. Radostits, O. M. ; Gay, C.C.; Hinchcliff, K.W. and Constable ,P.D.(2007). A text-book of the diseases of cattle, horses, sheep, pigs , and goats . $10^{\text {th }}$ edition, Saunders El-Sevier Ltd . pp:1223-1230.

14. Meyer RF, (2001). Knudsen RC. Foot-and-Mouth disease : a review of the virus and the symptoms. Journal of Environmental Health; 64: 21-23.

15. Abood BK, Shalash KH, Hussein ZS. (2009). Study of prevalence of FMD in cattle in middle and south of Iraq and detection of the causative serotype. Al-Anbar Journal of Veterinary Sciences; 2:82-86.

16. Saco y, Fina M, Gimenez R, Pato JP, Bassols A. (2008). Evaluation of serum cortisol, metabolic parameters, acute phase proteins, and faecal corticosterone as indicators of Stress in cows. The Veterinary Journal; $177: 439-441$.

17. Stilwell GT. (2009). Pain evaluation and control after routine intervention in cattle. Lisbona,; pp1-185.

18. Mosure WL, Meyer RA, Gudmundson J, (1998). Barth AD. Evaluation of possible methods to reduce pain associated with electroejaculation in bulls. Can. Vet. J; 39:504-506.

19. Wolf G, Yirmiya R, Kresil T, Goshen I, Weidenfeld J, Poole S, Shavit Y.( 2007). Interleukin-1 signaling modulates stress- induced analgesia. Brain, Behaviour and Immunity; 21:652-659.

20. Melian C, Peterson ME. (1998). Diagnosis and management of naturally occurring hypoadrenocorticism in small animals. Waltham Focus,; 8:2-7.

21. Bastos ADS, Boshoff CI, Keet DF, Bengis RG, Thombson GR. (2000). Natural transmission of foot and mouth disease virus between African buffalo (Syncerus caffer) and impla ( Aepyceros melampus) in the kruger national park, South Africa . epidemiol. Infec.; 124:1022-1031.

22. Mellor DJ, Cook CG, Stafford KJ. (2005). Quantifying some responses to pain as a stressor in the biology of animal stress, basic principles and implications for animal welfare, Moberg GP, Mench JA ed. CABI publishing, New York, USA; pp:171-198.

23. Salt JS. (1993). The carrier state in foot and mouth disease - an immunological review. British Veterinary Journal,; 149:207-223.

24. Bayazit V. (2009). Evaluation of Cortisol and Stress in Captive Animals . Australian Journal of Basic and Applied Sciences,; 3:1022-1031. 